\title{
EFEKTIVITAS PERKOTAAN GEMOLONG SEBAGAI PUSAT PELAYANAN PERMUKIMAN DI KABUPATEN SRAGEN
}

\author{
SRI MURDIATI RIN PERMATA SARI ${ }^{1}$ \\ Program Studi PERENCANAAN WilAyah DAN Kota \\ FAKULTAS TEKNIK \\ UNIVERSITAS SEBELAS MARET, SURAKARTA \\ EMAIL : SMRIRINPS@GMAIL.COM \\ ANA HARDiana ${ }^{2}$ \\ PROGRAM STUdi PERENCANAAN WILAYAH DAN KotA \\ FAKULTAS TEKNIK \\ UNIVERSITAS SEBELAS MARET, SURAKARTA \\ Rufia Andisetyana PUTri ${ }^{3}$ \\ PROGRAM STUdi PERENCANAAN WILAYAH DAN KoTA \\ FAKULTAS TEKNIK \\ UNIVERSITAS SEBELAS MARET, SURAKARTA
}

\begin{abstract}
The existence of dependency between residential service center with service area then resulted in the slice of service range from some service center adjacent. Urban Gemolong as a residential service center with six sub-districts as its service area (Gemolong, Miri, Sumberlawang, Plupuh, Kalijambe, Tanon), does not yet have a complete settlement service as well as the location of the big city (Solo, Porwodari, Boyolali) There is a tendency for the service area to not meet the needs of its services in urban Gemolong. The problem formulation in this research is how effectiveness of urban Gemolong as settlement service center in Sragen regency? The purpose of the study is the effectiveness of urban Gemolong as a settlement service center in Sragen regency. Research method in this research is deductive, with kind of quantitative research. Analytical techniques in this study is scoring analysis for suitability on each variable, and for assessment of its effectiveness by percentage approach. The conclusion obtained in this study is the effectiveness of urban Gemolong as a settlement service center in Sragen regency in the form of effective approach. Approaching effectively means that urban Gemolong as a settlement service center is in a near-successful position (approaching effectively) in fulfilling its role as a settlement service center in terms of goals, efficiency or affordability. Called approaching to succeed because of the three vaiabel approaches, there is an approach that states that viewed from the side of goals, urban Gemolong has been appropriate (effective from the side of the goal). From the approach of affordability and efficiency that is how the community to reach the service and how the availability of the number of facilities when compared with the population is still not appropriate (not yet effective). Urban Gemolong needs to improve the existing resettlement service especially from efficiency and affordability approach in order to fulfill its function and role as residential service center, in several ways that is the addition of the number of settlement service facilities, shifting and arranging the layout of the facilities so that the needs of facilities availability and affordability of the facilities are met
\end{abstract}

Keywords: Settlement service center, effective, Urban services

\section{PENDAHULUAN}

Wilayah merupakan suatu area geografis, teritorial atau tempat yang dapat berwujud sebagai suatu negara, negara bagian, provinsi, distrik(kabupaten), dan pedesaan. Tapi 
suatu wilayah pada umumnya tidak sekedar merujuk suatu tempat atau area, melainkan merupakan suatu kesatuan ekonomi, politik, sosial, administrasi, iklam hingga geografis, sesuai dengan tujuan pembangunan atau kajian [Rustiadi, 2011]. Beberapa pengertian tentang wilayah yang merupakan berasal dari berbagai sudut pandang menitik beratkan pada sesuatu, kemudian diklasifikasikan secara konseptual bahwa wilayah terbagi dalam 4 jenis yaitu, homogen, nodal, administratif dan perencanaaan [Pontoh dan Kustiwan, 2009].

Dari beberapa jenis wilayah tersebut, konsep wilayah yang sering dijumpai di Indonesia saat ini adalah wilayah nodal. Wilayah nodal adalah wilayah yang secara fungsional memiliki ketergantungan antara pusat (inti) dan wilayah belakangnya (hinterland). Tingkat ketergantungan ini dapat dilihat dari arus penduduk, faktor produksi, barang dan jasa, ataupun komunikasi dan transportasi [Pontoh dan Kustiwan, 2009]. Konsep wilayah nodal lebih berfokus pada peran pengendalian/pengaruh central atau pusat node serta hubungan ketergantungan pusat (nucleus) dan elemen-elemen sekelilingnya dibandingkan soal batas wilayah [Rustiadi, 2011]. Batas fisik dari setiap daerah pelayanan bersifat sangat baur dan dinamis serta berhirarki dan bertingkat berdasarkan fungsi pelayanan yang dijalankan oleh masingmasing noda yang ada. Pusat-pusat yang berorde tinggi kemudian memiliki kepadatan aktivitas, penduduk serta jenis sarana dan prasarana yang lebih tinggi dibanding pusat orde yang memiliki orde lebih rendah dengan kawasan hinterland yang kemudian lebih kecil [Rustiadi, 2011].

Pusat-pusat orde kemudian semakin lama semakin berkembang dan menimbulkan berbagai irisan pelayanan dengan kawasan pelayanan yang lain. Masyarakat pinggiran kabupaten yang berlokasi dekat dengan pusat kota tetangga cenderung untuk kemudian tertarik kepada pusat node dari kota tetangga. Hal ini membuat fungsi pusat pelayanan kabupaten tidak berjalan semestinya untuk melayani seluruh kawasan kabupaten.

Kabupaten Sragen, dengan luas wilayah sekitar 94.155 Ha serta jumlah penduduk sebesar 875.600 jiwa pada tahun 2014 kemudian menjadikan kabupaten ini didominasi dengan lahan pertanian dengan kantong-kantong permukiman yang terkonsentrasi dibeberapa tempat [BPS Kabupaten Sragen, 2015].

Kawasan Perkotaan Gemolong, yang berada di Kabupaten Sragen merupakan kecamatan di Kabupaten Sragen dan sering disebut dengan sragen ke-dua ini merupakan kawasan dengan tingkat ordo ke-II dibawah ibu kota kabupaten dan sedang mengalami perkembangan dan pembangunan yang intensive serta berada pada hirarki wilayah yaitu pkl-p (Pusat Kegiatan Lokal yang dipromosikan). Status sebagai PKL-p ini kemudian menjadikan gemolong sebagai pusat kota bagi kawasan pelayanannya. Kawasan pelayanan dari Perkotaan Gemolong ini sendiri melingkupi enam kecamatan (Tanon, Miri, Sumberlawang, Kalijambe, Plupuh serta Gemolong) yang berbatasan dengan Kota Surakarta di Selatan, Boyolali di Barat dan Grobogan di sebelah utara [BAPPEDA Kabupaten Sragen, 2010].

Selain itu, berdasarkan arahan rencana yang ada pada RTRW Kabupaten Sragen tahun 2011-2031 disebutkan bahwa peruntukan gemolong sebagai pusat pelayanan permukiman perkotaan, walaupun perkotaan Gemolong telah ditetapkan sebagai pusat permukiman, letak geografis gemolong dan wilayah pelayanannya yang berdekatan dengan kota besar membuat wilayah hinterland dari kecamatan gemolong yang berada di pinggir-pinggir cenderung untuk tertarik kepada node yang lebih tinggi ordenya walaupun di wilayah tetangga [BAPPEDA Kabupaten Sragen, 2010]. Dilihat dari sisi ketersediaan beberapa 
fasilitas berdasarkan standart perkotaan terkait fasilitas yang harus ada terutama fasilitas pendidikan, Kecamatan Gemolong ini masih kekurangan karena tidak adanya universitas atau perguruan tinggi serta akademi untuk memenuhi kebutuhan pendidikan penduduk yang ada juga untuk fasilitas kebudayaan belum terdapat bioskop dan teater sesuai standart perkotaan yang seharusnya seperti terdapat pada BSN (2004). Sehingga untuk wilayah pelayanan ataupun wilayah perkotaan sendiri harus pergi keluar untuk memenuhi kebutuhan tersebut.

Melihat fakta-fakta diatas kemudian daat dirumuskan untuk rumusan masalah dari penelitian ini adalah : "Bagaimana efektivitas perkotaan Gemolong sebagai pusat pelayanan permukiman di Kabupaten Sragen?”

\section{TINJAUAN PUSTAKA}

\subsection{Efektivitas}

Definisi dari efektivitas adalah suatu keadaan yang menunjukan tingkatan keberhasilan manajemen dalam mencapai tujuan yang telah ditetapkan terlebih dahulu menurut Sastradipoera (1994), selain itu dapat diartikan Eektivitas adalah pengukuran dalam tercapainya tujuan yang ditentukan sebelumnya (Handayaningrat 1994,16).

Dengan menggunakan sintesis teori, kemudian dirumuskan untuk pendekatan efektivitas adalah sebagai berikut :

Tabel 1.Pendekatan dan Kriteria Efektivitas

\begin{tabular}{|l|l|l|l|}
\hline $\begin{array}{c}\text { Cameron } \\
\text { (1980) }\end{array}$ & \multicolumn{1}{|c|}{$\begin{array}{c}\text { Gibson } \\
\text { (1985) }\end{array}$} & Sintesis & Penjelasan \\
\hline Tujuan & Produksi & Tujuan & $\begin{array}{l}\text { Outuput yang } \\
\text { sesuai } \\
\text { dengan } \\
\text { rencana awal }\end{array}$ \\
\hline $\begin{array}{l}\text { Teori } \\
\text { Sistem }\end{array}$ & Efisiensi & Efisiensi & $\begin{array}{l}\text { Perbandingan } \\
\text { input dan } \\
\text { output }\end{array}$ \\
\cline { 2 - 5 } & Kepuasan & Kepuasan & $\begin{array}{l}\text { Keberhasilan } \\
\text { dari } \\
\text { pemenuhan } \\
\text { kebutuhan } \\
\text { (persepsi } \\
\text { konsumen) }\end{array}$ \\
\cline { 2 - 4 } & Kedaptasian & Kedaptasian & $\begin{array}{l}\text { Tanggap } \\
\text { perubahan } \\
\text { dan kondisi } \\
\text { atau tuntutan } \\
\text { sekitar }\end{array}$ \\
\cline { 2 - 4 } & & Pengem & Memperbesar \\
\hline
\end{tabular}

\begin{tabular}{|c|l|l|l|}
\hline $\begin{array}{c}\text { Cameron } \\
\text { (1980) }\end{array}$ & $\begin{array}{c}\text { Gibson } \\
\text { (1985) }\end{array}$ & Sintesis & Penjelasan \\
\hline & bangan & bangan & $\begin{array}{l}\text { kapasitas dan } \\
\text { potensi, } \\
\text { proyeksi dan } \\
\text { oitcome }\end{array}$ \\
\hline
\end{tabular}

Sumber :Cameron (1980); Gibson (1985)

\subsection{Pusat Pelayanan Permukiman}

Kota pada dasarnya merupakan pusat kegiatan dalam lingkup wilayah yang lebih luas. Peranan kota sebagai pusat kegiatan dalam suatu wilayah nasional ataupun local telah banyak ditunjukkan dalam berbagai litelatur barat yang pada intinya menyimpulkan bahwa kota berperan sebagai pusat industry manufaktur dan pusat kegiatan pelayanan (Pontoh 2009, 139). Menurut ahli, (B. tjahjati S Soegijoko, 2005 dalam , Pontoh 2009, 139) menggambarkan peran kota sebagai pusat kegiatan pelayanan. Kegiatan pelayanan ini biasanya memberikan kontribusi terbesar dan meningkatkan pada GNP.

Sedangkan berdasar pada National Urban Development Strategy (NUDS, 1985 dalam Pontoh 2009, 141) mengidentifikasi fungsi kota salah satunya sebagai hinterland services yang merupakan fungsi utama dari kebanyakan kota. Yaitu sebagai penyedia pelayanan /jasa pada wilayah belakangnya (hinterland). Fungsi utama ini terkait dengan ekonomi . terkait bagaimana petani (produsen) yang kemudian mengangkut barang produknya untuk kemudian dipasarkan di perkotaan. Kota menyediakan fasilitas pemasaran, dan jasa/pelayanan, tetapi juga menjual input yang dibutuhkan untuk produksi, serta barang konsumsi untuk penduduk hinterland itu sendiri.

Sehingga dikatakan bahwa pusat pelayanan memiliki fungsi sebagai tempat terkonsentrasinya penduduk, sebagai pusat pelayanan untuk kawasan hinterland nya, pasar bagi komoditasi baik pertanian dan industri serta lokasi pemusatan industri manufactur serta lokasi dimana seluruh fasilitas pelayanan terpusat.(Muta'ali 2013, 161) 


\subsection{Efelktivitas Pusat Pelayanan Permukiman}

Efektivitaspusat pelayanan permukiman merupakan hasil sintesa teori dari efektivitas dan pusat pelayanan permukiman yang kemudian menghasilkan sintesa sebagai berikut :

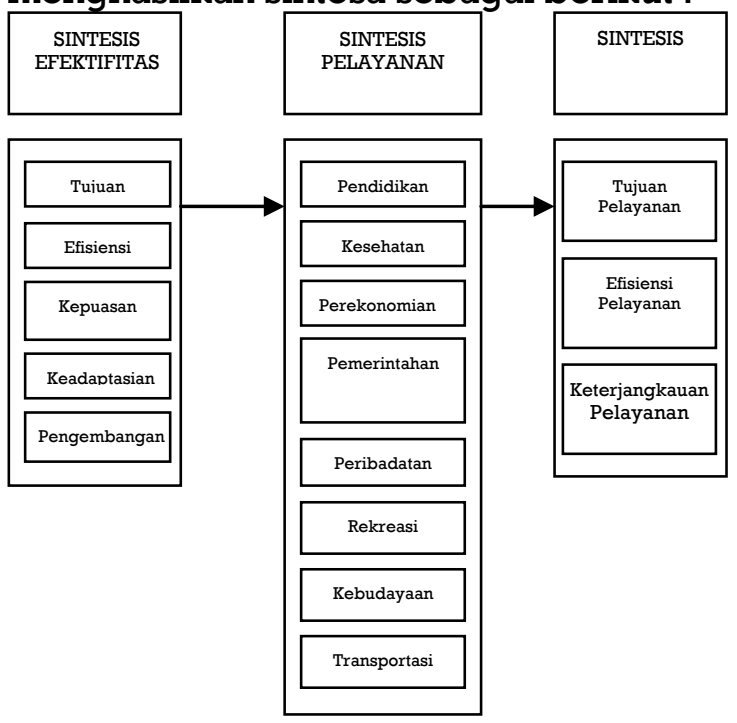

Gambar 1. Grafik Efektifitas Pelayanan Kota [Cameron (1980); Gibson (1985); Chiara (1995); Mirsa (2012); SNI 03-1733-2004]

Variabel dari efektivitas pusat pelayanan permukiman jika dijabarkan beserta definisi operasionalnya adalah sebagai berikut :

Tabel 2. Definisi Operasional Variabel Efektivitas Pusat Pelayanan Permukiman

\begin{tabular}{|l|l|l|}
\hline No & \multicolumn{1}{|c|}{ Variabel } & \multicolumn{2}{|l|}{ Definisi Operasional } \\
\hline & & $\begin{array}{l}\text { Ketercapaian dari } \\
\text { fungsi utama pada tiap } \\
\text { pelayanan (Kualitas } \\
\text { Pelayanan) pada } \\
\text { eksisting di lapangan } \\
\text { dibandingkan dengan } \\
\text { standart atau teori } \\
\text { pelayanan yang } \\
\text { berlaku. }\end{array}$ \\
\hline 2 & $\begin{array}{l}\text { Tujuan } \\
\text { Pelayanan }\end{array}$ & $\begin{array}{l}\text { Perbandingan jumlah } \\
\text { kebutuhan pelayanan } \\
\text { yang seharusnya } \\
\text { dengan keadaan } \\
\text { eksisting yang ada }\end{array}$ \\
\hline
\end{tabular}

\begin{tabular}{|c|c|l|}
\hline No & \multicolumn{1}{|c|}{ Variabel } & Definisi Operasional \\
\hline & & (kuantitas) \\
\hline 3 & & $\begin{array}{l}\text { Terkait dengan } \\
\text { keterjangkauan } \\
\text { pelayanan untuk } \\
\text { dapat dijangkau oleh } \\
\text { masyarakat dari sisi } \\
\text { jarak. }\end{array}$ \\
\hline
\end{tabular}

Sumber :Cameron (1980); Gibson (1985); Chiara (1995); Mirsa (2012); SNI 03-1733-2004

\section{METODE PENELITIAN}

Metode pembahasan ini berisi tentang variabel penelitian, tahapan pelaksanaan penelitian dan analisis penelitian.

\subsection{Variabel Penelitian}

Variabel penelitian adalah konstruk atau sifat yang akan dipelajari [Sugiyono, 2011] atau juga bisa dikatakan bahwa variabel adalah suatu kualitas dimana peneliti mempelajari dan menarik kesimpulan darinya [Sugiyono, 2011]. Sehingga variabel dalam penelitian ini sendiri adalah suatu atribut atau sifat yang merupakan hasil sintesa baik dari teori efektivitas dan jenis pelayanan dalam pusat pelayanan yang kemudian saling disilangkan untuk mendapatkan variasi sehingga kemudian menjadi landasan dalam pengukuran untuk kemudian dapat di tarik kesimpulan. Variabel penelitian ini ada tiga yaitu tujuan pelayanan, efisiensi pelayanan dan keterjangkauan pelayanan yang masing-masing memiliki sub variabel yaitu delapan pelayanan berupa pendidikan, kesehatan, perekonomian, pemerintahan,peribadatan, kebudayaan, rekreasi, dan transportasi. Berikut adalah variabel beserta indikator kesesuaian untuk masing-masing sub variabel dalam penelitian ini :

Tabel 3. Indikator Variabel Efektivitas Pusat Pelayanan Permukiman

\begin{tabular}{|c|c|c|c|c|c|c|c|}
\hline \multirow[b]{2}{*}{ Variabel } & \multirow{2}{*}{$\begin{array}{l}\text { Definisi } \\
\text { Variabel }\end{array}$} & \multirow[b]{2}{*}{ Sub-Variabel } & \multirow[b]{2}{*}{ Jenis Sarana } & \multirow[b]{2}{*}{ Parameter } & \multirow[b]{2}{*}{ Sumber } & \multicolumn{2}{|c|}{ Indikator } \\
\hline & & & & & & Sesuai (2) & $\begin{array}{c}\text { Tidak Sesuai } \\
\text { (1) }\end{array}$ \\
\hline \multirow[t]{2}{*}{$\begin{array}{c}\text { Tujuan } \\
\text { Pelayanan }\end{array}$} & $\begin{array}{l}\text { Tercapaianya } \\
\text { fungsi dari } \\
\text { masing-masing } \\
\text { pelayanan/ } \\
\text { tujuan } \\
\text { pelayanan }\end{array}$ & pendidikan & Perpustakaan & $\begin{array}{ll}\text { 1. Jumlah koleksi } \\
\text { anak } 500 \\
\text { 2. Koleksi dewasa } \\
1000 \\
\text { 3. Referensi anak } \\
50 \\
\text { 4. Referensi } \\
\text { dewasa } 20\end{array}$ & $\begin{array}{c}\text { Standart } \\
\text { Nasional } \\
\text { Perpustakaa } \\
\text { n, } 2011\end{array}$ & $\begin{array}{l}\text { Memenuhi } \\
\text { seluruh } \\
\text { standart dari } \\
\text { parameter }\end{array}$ & $\begin{array}{c}\text { Terdapat } \\
\text { standartyang } \\
\text { tidak } \\
\text { terpenuhi }\end{array}$ \\
\hline & & & museum & 1. Terdapat 20 & PP RI No. 66 & Memenuhi & Terdapat \\
\hline
\end{tabular}




\begin{tabular}{|c|c|c|c|c|c|c|c|}
\hline \multirow[b]{2}{*}{ Variabel } & \multirow[b]{2}{*}{$\begin{array}{l}\text { Definisi } \\
\text { Variabel }\end{array}$} & \multirow[b]{2}{*}{ Sub-Variabel } & \multirow[b]{2}{*}{ Jenis Sarana } & \multirow[b]{2}{*}{ Parameter } & \multirow[b]{2}{*}{ Sumber } & \multicolumn{2}{|c|}{ Indikator } \\
\hline & & & & & & Sesuai (2) & $\begin{array}{c}\text { Tidak Sesuai } \\
\text { (1) }\end{array}$ \\
\hline & & & & $\begin{array}{ll}\text { 2. } & \text { koleksi } \\
\text { pamdapat ruang } \\
\text { pameran }\end{array}$ & $\begin{array}{c}\text { Tahun } 2015 \\
\text { tentang } \\
\text { Museum }\end{array}$ & $\begin{array}{c}\text { seluruh } \\
\text { standart dari } \\
\text { parameter }\end{array}$ & $\begin{array}{l}\text { standart yang } \\
\text { tidak } \\
\text { terpenuhi }\end{array}$ \\
\hline & & & $\begin{array}{l}\text { Perguruan } \\
\text { tinggi }\end{array}$ & $\begin{array}{ll} & \text { Program } \\
& \text { pendidikan : } \\
\text { 1. } & \text { diploma, } \\
2 . & \text { sarjana, } \\
\text { 3. } & \text { magister, } \\
4 . & \text { spesialis dan } \\
5 . & \text { doktor } \\
\end{array}$ & $\begin{array}{c}\text { UU No.20 } \\
\text { tahun } 2003 \\
\text { pasal } 19 \text { ayat } \\
1\end{array}$ & $\begin{array}{c}\text { Menyelenggar } \\
\text { akan } 5 \\
\text { program } \\
\text { pendidikan }\end{array}$ & $\begin{array}{c}\text { Penyelenggara } \\
\text { kan program } \\
\text { pendidikan } \\
\text { kurang dari } 5 \\
\text { program }\end{array}$ \\
\hline & & Kesehatan & Puskesmas & $\begin{array}{l}\text { Jenis Pelayanan: } \\
\text { 1. Rawat Jalan } \\
\text { 2. Pelayanan gawat } \\
\text { darurat } \\
\text { 3. Pelayanan satu } \\
\text { hari } \\
\text { 4. Pelayanan rawat } \\
\text { inap } \\
\end{array}$ & $\begin{array}{l}\text { Permenkes } \\
\text { No. } 75 \text { tahun } \\
2014 \\
\text { tentang } \\
\text { puskesmas }\end{array}$ & $\begin{array}{c}\text { Melayani } \\
\text { empat jenis } \\
\text { pelayanan atau } \\
\text { lebih }\end{array}$ & $\begin{array}{l}\text { Melayani } \\
\text { kurang dari } \\
\text { empat jenis } \\
\text { pelayanan }\end{array}$ \\
\hline & & & Rumah sakit & $\begin{array}{l}\text { Spesialis dasar: } \\
\text { 1. Penyakit dalam } \\
\text { 2. Bedah } \\
\text { 3. Kandungan } \\
\text { 4. Anak }\end{array}$ & $\begin{array}{l}\text { (Kepmenkes } \\
\text { No.51 } \\
\text { Menkes/SK/ } \\
\text { II/1979). }\end{array}$ & $\begin{array}{c}\text { Memenuhi } \\
\text { kedua standart } \\
\text { pelayanan } \\
\text { (tempat tidur } \\
\text { dan jenis } \\
\text { spesialis) } \\
\end{array}$ & $\begin{array}{c}\text { Terdapat } \\
\text { standart yang } \\
\text { tidak } \\
\text { terpenuhi }\end{array}$ \\
\hline & & Perekonomian & Pertokoan & $\begin{array}{l}\text { Jenis pelayanan: } \\
\text { 1. Menjual } \\
\text { kebutuhan sehari- } \\
\text { hari } \\
\text { 2. Pelayanan jasa } \\
\text { seperti wartel / } \\
\text { fotocopy, dsb } \\
\text { 3. Pelayanan } \\
\text { pendukung } \\
\text { seperti warung } \\
\text { makan atau kantor }\end{array}$ & $\begin{array}{c}\text { SNI 03-1733- } \\
1989\end{array}$ & $\begin{array}{c}\text { Terdapat tiga } \\
\text { jenis } \\
\text { pelayanan }\end{array}$ & $\begin{array}{l}\text { Terdapat } \\
\text { pelayanan } \\
\text { yang tidak } \\
\text { terpenuhi }\end{array}$ \\
\hline & & & $\begin{array}{c}\text { Pusat } \\
\text { perbelajaan }\end{array}$ & $\begin{array}{l}\text { Aktivitas utama } \\
\text { perbelanjaan dan } \\
\text { aktivitas } \\
\text { pendukung: } \\
\text { 1. Tempat rekreasi } \\
\text { 2. Restoran } \\
\text { 3. Hotel } \\
\text { 4. Layanan medis } \\
\text { 5. Kantor } \\
\text { 6. Tempat tinggal }\end{array}$ & 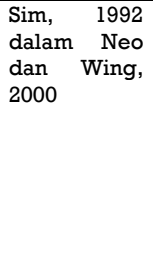 & $\begin{array}{c}\text { Terdapat } \\
\text { aktivitas utama } \\
\text { dan } 6 \text { aktivitas } \\
\text { pendukung }\end{array}$ & $\begin{array}{c}\text { Terdapat } \\
\text { aktivitas utama } \\
\text { atau } \\
\text { pendukung } \\
\text { yang tidak } \\
\text { terpenuhi }\end{array}$ \\
\hline & & & pasar & $\begin{array}{l}\text { Terdapat } 500 \text { kios, } \\
\text { dan } 500 \text { los }\end{array}$ & $\begin{array}{l}\text { SNI 03-1733- } \\
2004\end{array}$ & $\begin{array}{l}\text { Memiliki } 500 \\
\text { kios dan } 500 \\
\text { los atau lebih. }\end{array}$ & $\begin{array}{c}\text { Kios dan atau } \\
\text { los kurang dari } \\
500 \\
\end{array}$ \\
\hline & & $\begin{array}{c}\text { Pelayanan } \\
\text { Pemerintahan }\end{array}$ & Kantor Pos & $\begin{array}{l}\text { Jenis pelayanan: } \\
\text { 1. Pelayanan Pokok } \\
\text { (surat pos, paket } \\
\text { pos, weselpos, } \\
\text { giro, cekpos) } \\
\text { 2. Pelayanan } \\
\text { Tambahan } \\
\text { (pelayanan } \\
\text { disamping } \\
\text { penyelenggaraan } \\
\text { pokok) } \\
\text { 3. Pelayanan Khusus } \\
\text { (atas permintaan } \\
\text { pengirim atau } \\
\text { penerima) } \\
\text { 4. Pelayanan } \\
\text { Keagenan } \\
\text { (diselenggarakan } \\
\text { oleh perum untuk } \\
\text { kepentingan } \\
\text { pihak tertentu) }\end{array}$ & $\begin{array}{l}\text { PP RI No.37 } \\
\text { Tahun } 1985 \\
\text { tentang } \\
\text { Penyelengg } \\
\text { araan Pos }\end{array}$ & $\begin{array}{c}\text { Melayani } \\
\text { seluruh } \\
\text { pelayanan } \\
\text { sesuai standart }\end{array}$ & $\begin{array}{c}\text { Terdapat } \\
\text { standart jenis } \\
\text { pelayanan } \\
\text { yang tidak } \\
\text { dilayani }\end{array}$ \\
\hline & & & Kantor Polisi & $\begin{array}{l}\text { Jenis Pelayanan : } \\
\text { 1. SPKT } \\
\text { 2. SIM } \\
\text { 3. BPKB / STNK } \\
\text { 4. SKCK } \\
\text { 5. Cek Kasus } \\
\text { 6. Ijin Keramaian } \\
\text { 7. Pengamanan } \\
\quad \text { Objek Khusus } \\
\text { 8. Pengawalan Jalan }\end{array}$ & $\begin{array}{l}\text { www.polri.g } \\
\text { o.id }\end{array}$ & $\begin{array}{c}\text { Terdapat } 8 \\
\text { jenis } \\
\text { pelayanan }\end{array}$ & $\begin{array}{c}\text { Jenis } \\
\text { pelayanan } \\
\text { kurang dari } 8\end{array}$ \\
\hline & & & Kantor & Jenis Kegiatan : & & Terdapat 3 & Terdapat \\
\hline
\end{tabular}


Sri Murdiati Rin Permata Sari, Efektivitas Pusat Pelayanan...

\begin{tabular}{|c|c|c|c|c|c|c|c|}
\hline \multirow[b]{2}{*}{ Variabel } & \multirow[b]{2}{*}{$\begin{array}{c}\text { Definisi } \\
\text { Variabel }\end{array}$} & \multirow[b]{2}{*}{ Sub-Variabel } & \multirow[b]{2}{*}{ Jenis Sarana } & \multirow[b]{2}{*}{ Parameter } & \multirow[b]{2}{*}{ Sumber } & \multicolumn{2}{|c|}{ Indikator } \\
\hline & & & & & & Sesuai (2) & $\begin{array}{c}\text { Tidak Sesuai } \\
\text { (1) }\end{array}$ \\
\hline & & & $\begin{array}{l}\text { Pemadam } \\
\text { Kebakaran }\end{array}$ & $\begin{array}{l}\text { 1. Penanggulangan } \\
\text { Kebakaran } \\
\text { 2. Penyuluhan } \\
\text { 3. Pencegahan } \\
\text { Kebakaran }\end{array}$ & & $\begin{array}{c}\text { atau lebih jenis } \\
\text { kegiatan }\end{array}$ & $\begin{array}{l}\text { kurang dari } 3 \\
\text { jenis kegiatan }\end{array}$ \\
\hline & & Peribadatan & Masjid & $\begin{array}{l}\text { Kegiatan utama: } \\
\text { peribadatan } \\
\text { Kegiatan } \\
\text { Pendukung: } \\
\text { 1. Pendidikan } \\
\text { 2. Perayaan Hari }\end{array}$ & & $\begin{array}{c}\text { Terdapat } \\
\text { kegiatan utama } \\
\text { dan dua atau } \\
\text { lebih kegiatan } \\
\text { pendukung }\end{array}$ & $\begin{array}{c}\text { Terdapat } \\
\text { kegiatan utama } \\
\text { atau } \\
\text { pendukung } \\
\text { yang tidak } \\
\text { terpenuhi }\end{array}$ \\
\hline & & & Gereja & Besar & & $\begin{array}{c}\text { Terdapat } \\
\text { kegiatan utama } \\
\text { dan dua atau } \\
\text { lebih kegiatan } \\
\text { pendukung }\end{array}$ & $\begin{array}{c}\text { Terdapat } \\
\text { kegiatan utama } \\
\text { atau } \\
\text { pendukung } \\
\text { yang tidak } \\
\text { terpenuhi } \\
\end{array}$ \\
\hline & & Rekreasi & Taman Kota & $\begin{array}{l}\text { Jenis kegaitan: } \\
\text { 1. Rekreasi } \\
\text { 2. Edukasi } \\
\text { 3. Olahraga } \\
\end{array}$ & $\begin{array}{l}\text { Permen No. } \\
05 \text { tahun } \\
2008\end{array}$ & $\begin{array}{c}\text { Terdapat } 3 \\
\text { jenis kegiatan }\end{array}$ & $\begin{array}{c}\text { Terdapat } \\
\text { kurang dari } \\
\text { tiga jenis } \\
\text { kegaitan } \\
\end{array}$ \\
\hline & & kebudayaan & theater & $\begin{array}{l}\text { Jenis kegiatan : } \\
\text { 1. Pembelajaran } \\
\text { 2. Pertunjukan }\end{array}$ & & $\begin{array}{l}\text { Terdapat dua } \\
\text { atau lebih jenis } \\
\text { kegiatan }\end{array}$ & $\begin{array}{c}\text { Terdapat } \\
\text { kurang dari } 2 \\
\text { jenis kegiatan }\end{array}$ \\
\hline & & transpotrtasi & Terminal & $\begin{array}{l}\text { Jenis kegiatan: } \\
\text { 1. Pemberhentian } \\
\text { 2. Penjemputan } \\
\text { 3. Menunggu }\end{array}$ & & $\begin{array}{c}\text { Terdapat } \\
\text { ketiga jenis } \\
\text { kegiatan }\end{array}$ & $\begin{array}{c}\text { Terdapat } \\
\text { kurang dari } 3 \\
\text { jenis kegiatan }\end{array}$ \\
\hline & & & $\begin{array}{c}\text { Stasiun kereta } \\
\text { api }\end{array}$ & $\begin{array}{l}\text { Jenis kegiatan: } \\
\text { 1. Pemberhentian } \\
\text { 2. Penjemputan } \\
\text { 3. Menunggu }\end{array}$ & & $\begin{array}{l}\text { Terdapat } \\
\text { ketiga jenis } \\
\text { kegiatan }\end{array}$ & $\begin{array}{c}\text { Terdapat } \\
\text { kurang dari } 3 \\
\text { jenis kegiatan }\end{array}$ \\
\hline $\begin{array}{c}\text { Efisiensi } \\
\text { Pelayanan } \\
\text { Permukiman }\end{array}$ & $\begin{array}{c}\text { Jumlah } \\
\text { kebutuhan dan } \\
\text { ketersediaan }\end{array}$ & pendidikan & Perpustakaan & $\begin{array}{c}\text { Terdapat l sarana } \\
\text { di kawasan } \\
\text { perkotaan }\end{array}$ & $\begin{array}{c}\text { Rinaldi } \\
\text { Mirsa, } 2012\end{array}$ & $\begin{array}{l}\text { Terdapat l } \\
\text { atau lebih } \\
\text { sarana }\end{array}$ & $\begin{array}{c}\text { Tidak ada } \\
\text { sarana }\end{array}$ \\
\hline & $\begin{array}{l}\text { eksisting di } \\
\text { lapangan }\end{array}$ & & museum & $\begin{array}{c}\text { Terdapat l sarana } \\
\text { di kawasan } \\
\text { perkotaan }\end{array}$ & & $\begin{array}{c}\text { Terdapat l } \\
\text { atau lebih } \\
\text { sarana }\end{array}$ & $\begin{array}{l}\text { Tidak ada } \\
\text { sarana }\end{array}$ \\
\hline & & & $\begin{array}{l}\text { Perguruan } \\
\text { tinggi }\end{array}$ & $\begin{array}{c}\text { Terdapat l sarana } \\
\text { di kawasan } \\
\text { perkotaan }\end{array}$ & & $\begin{array}{c}\text { Terdapat l } \\
\text { atau lebih } \\
\text { sarana }\end{array}$ & $\begin{array}{l}\text { Tidak ada } \\
\text { sarana }\end{array}$ \\
\hline & & Kesehatan & Puskesmas & $\begin{array}{c}\text { Terdapat } 2 \text { sarana } \\
\text { di kawasan } \\
\text { perkotaan }\end{array}$ & & $\begin{array}{c}\text { Terdapat } 2 \\
\text { atau lebih } \\
\text { sarana }\end{array}$ & $\begin{array}{c}\text { Terdapat } 1 \\
\text { atau tidak ada } \\
\text { sarana }\end{array}$ \\
\hline & & & Rumah sakit & $\begin{array}{c}\text { Terdapat l sarana } \\
\text { di kawasan } \\
\text { perkotaan }\end{array}$ & & $\begin{array}{l}\text { Terdapat l } \\
\text { atau lebih } \\
\text { sarana }\end{array}$ & $\begin{array}{c}\text { Tidak ada } \\
\text { sarana }\end{array}$ \\
\hline & & Perekonomian & Pertokoan & $\begin{array}{c}\text { Terdapat } 5 \text { sarana } \\
\text { di kawasan } \\
\text { perkotaan }\end{array}$ & & $\begin{array}{c}\text { Terdapat } 5 \\
\text { atau lebih } \\
\text { sarana }\end{array}$ & $\begin{array}{c}\text { Terdapat } \\
\text { kurang dari } 5 \\
\text { sarana } \\
\end{array}$ \\
\hline & & & $\begin{array}{c}\text { Pusat } \\
\text { perbelajaan }\end{array}$ & $\begin{array}{l}\text { Terdapat l sarana } \\
\text { di kawasan } \\
\text { perkotaan }\end{array}$ & & $\begin{array}{l}\text { Terdapat l } \\
\text { atau lebih } \\
\text { sarana }\end{array}$ & $\begin{array}{c}\text { Tidak ada } \\
\text { sarana }\end{array}$ \\
\hline & & & pasar & $\begin{array}{c}\text { Terdapat l sarana } \\
\text { di kawasan } \\
\text { perkotaan }\end{array}$ & & $\begin{array}{l}\text { Terdapat l } \\
\text { atau lebih } \\
\text { sarana }\end{array}$ & $\begin{array}{c}\text { Tidak ada } \\
\text { sarana }\end{array}$ \\
\hline & & $\begin{array}{c}\text { Pelayanan } \\
\text { Pemerintahan }\end{array}$ & Kantor Pos & $\begin{array}{c}\text { Terdapat } 2 \text { sarana } \\
\text { di kawasan } \\
\text { perkotaan }\end{array}$ & & $\begin{array}{l}\text { Terdapat } 2 \\
\text { atau lebih } \\
\text { sarana }\end{array}$ & $\begin{array}{c}\text { Terdapat } 1 \\
\text { atau tidak ada } \\
\text { sarana }\end{array}$ \\
\hline & & & Kantor Polis & $\begin{array}{c}\text { Terdapat } 2 \text { sarana } \\
\text { di kawasan } \\
\text { perkotaan }\end{array}$ & & $\begin{array}{c}\text { Terdapat } 2 \\
\text { atau lebih } \\
\text { sarana }\end{array}$ & $\begin{array}{c}\text { Terdapat } 1 \\
\text { atau tidak ada } \\
\text { sarana }\end{array}$ \\
\hline & & & $\begin{array}{c}\text { Kantor } \\
\text { Pemadam } \\
\text { Kebakaran } \\
\end{array}$ & $\begin{array}{c}\text { Terdapat } 2 \text { sarana } \\
\text { di kawasan } \\
\text { perkotaan }\end{array}$ & & $\begin{array}{c}\text { Terdapat } 2 \\
\text { atau lebih } \\
\text { sarana }\end{array}$ & $\begin{array}{c}\text { Terdapat } 1 \\
\text { atau tidak ada } \\
\text { sarana }\end{array}$ \\
\hline & & Peribadatan & Masjid & $\begin{array}{l}\text { Terdapat } 2 \text { sarana } \\
\text { di kawasan } \\
\text { perkotaan }\end{array}$ & & $\begin{array}{l}\text { Terdapat } 2 \\
\text { atau lebih } \\
\text { sarana }\end{array}$ & $\begin{array}{c}\text { Terdapat l } \\
\text { atau tidak ada } \\
\text { sarana }\end{array}$ \\
\hline & & & Gereja & $\begin{array}{c}\text { Terdapat l sarana } \\
\text { di kawasan } \\
\text { perkotaan }\end{array}$ & & $\begin{array}{l}\text { Terdapat l } \\
\text { atau lebih } \\
\text { sarana }\end{array}$ & $\begin{array}{c}\text { Tidak ada } \\
\text { sarana }\end{array}$ \\
\hline & & Rekreasi & Taman Kota & $\begin{array}{c}\text { Terdapat } 3 \text { sarana } \\
\text { di kawasan } \\
\text { perkotaan }\end{array}$ & & $\begin{array}{l}\text { Terdapat } 3 \\
\text { atau lebih } \\
\text { sarana }\end{array}$ & $\begin{array}{c}\text { Terdapat } \\
\text { kurang dari } 3 \\
\text { sarana } \\
\end{array}$ \\
\hline & & kebudayaan & theater & $\begin{array}{c}\text { Terdapat l sarana } \\
\text { di kawasan } \\
\text { perkotaan }\end{array}$ & & $\begin{array}{l}\text { Terdapat l } \\
\text { atau lebih } \\
\text { sarana }\end{array}$ & $\begin{array}{c}\text { Tidak ada } \\
\text { sarana }\end{array}$ \\
\hline & & transpotrtasi & Terminasl & $\begin{array}{l}\text { Terdapat l sarana } \\
\text { di kawasan } \\
\text { perkotaan }\end{array}$ & & $\begin{array}{l}\text { Terdapat l } \\
\text { atau lebih } \\
\text { sarana }\end{array}$ & $\begin{array}{c}\text { Tidak ada } \\
\text { sarana }\end{array}$ \\
\hline & & & $\begin{array}{l}\text { Stasiun kereta } \\
\text { api }\end{array}$ & $\begin{array}{l}\text { Terdapat l sarana } \\
\text { di kawasan } \\
\text { perkotaan }\end{array}$ & & $\begin{array}{l}\text { Terdapat l } \\
\text { atau lebih } \\
\text { sarana }\end{array}$ & $\begin{array}{l}\text { Tidak ada } \\
\text { sarana }\end{array}$ \\
\hline
\end{tabular}




\begin{tabular}{|c|c|c|c|c|c|c|c|}
\hline \multirow[b]{2}{*}{ Variabel } & \multirow{2}{*}{$\begin{array}{c}\text { Definisi } \\
\text { Variabel }\end{array}$} & \multirow[b]{2}{*}{ Sub-Variabel } & \multirow[b]{2}{*}{ Jenis Sarana } & \multirow[b]{2}{*}{ Parameter } & \multirow[b]{2}{*}{ Sumber } & \multicolumn{2}{|c|}{ Indikator } \\
\hline & & & & & & Sesuai (2) & $\begin{array}{c}\text { Tidak Sesuai } \\
\text { (1) }\end{array}$ \\
\hline \multirow[t]{17}{*}{$\begin{array}{l}\text { Keterjangka } \\
\text { uan }\end{array}$} & \multirow{17}{*}{$\begin{array}{c}\text { Besarnya } \\
\text { wilayah } \\
\text { terjangkau } \\
\text { berdasarkan } \\
\text { standart jarak } \\
\text { jangkauan } \\
\text { sarana } \\
\text { pelayanan }\end{array}$} & \multirow[t]{3}{*}{ pendidikan } & Perpustakaan & $\begin{array}{l}\text { Luas jangkauan } \\
\text { berdasarkan } \\
\text { standart jarak } \\
\text { jangkauan } \\
\text { pelayanan }\end{array}$ & \multirow{17}{*}{$\begin{array}{c}\text { SNI 03-1733- } \\
2004 \\
\text { Tentang Tata } \\
\text { Cara } \\
\text { Perencanaan } \\
\text { Lingkungan } \\
\text { Perumahan } \\
\text { di Perkotaan } \\
\text { dan Chiara, } \\
1995\end{array}$} & $\begin{array}{c}\text { Seluruh } \\
\text { kawasan } \\
\text { terjangkau }\end{array}$ & $\begin{array}{c}\text { Terdapat } \\
\text { kawasan yang } \\
\text { tidak } \\
\text { terjangkau }\end{array}$ \\
\hline & & & museum & $\begin{array}{l}\text { Luas jangkauan } \\
\text { berdasarkan } \\
\text { standart jarak } \\
\text { jangkauan } \\
\text { pelayanan }\end{array}$ & & $\begin{array}{l}\text { Seluruh } \\
\text { kawasan } \\
\text { terjangkau }\end{array}$ & $\begin{array}{c}\text { Terdapat } \\
\text { kawasan yang } \\
\text { tidak } \\
\text { terjangkau }\end{array}$ \\
\hline & & & $\begin{array}{l}\text { Perguruan } \\
\text { tinggi }\end{array}$ & $\begin{array}{l}\text { Luas jangkauan } \\
\text { berdasarkan } \\
\text { standart jarak } \\
\text { jangkauan } \\
\text { pelayanan }\end{array}$ & & $\begin{array}{c}\text { Seluruh } \\
\text { kawasan } \\
\text { terjangkau }\end{array}$ & $\begin{array}{c}\text { Terdapat } \\
\text { kawasan yang } \\
\text { tidak } \\
\text { terjangkau }\end{array}$ \\
\hline & & \multirow[t]{2}{*}{ Kesehatan } & Puskesmas & $\begin{array}{l}\text { Luas jangkauan } \\
\text { berdasarkan } \\
\text { standart jarak } \\
\text { jangkauan } \\
\text { pelayanan }\end{array}$ & & $\begin{array}{c}\text { Seluruh } \\
\text { kawasan } \\
\text { terjangkau }\end{array}$ & $\begin{array}{c}\text { Terdapat } \\
\text { kawasan yang } \\
\text { tidak } \\
\text { terjangkau }\end{array}$ \\
\hline & & & Rumah sakit & $\begin{array}{l}\text { Luas jangkauan } \\
\text { berdasarkan } \\
\text { standart jarak } \\
\text { jangkauan } \\
\text { pelayanan }\end{array}$ & & $\begin{array}{c}\text { Seluruh } \\
\text { kawasan } \\
\text { terjangkau }\end{array}$ & $\begin{array}{c}\text { Terdapat } \\
\text { kawasan yang } \\
\text { tidak } \\
\text { terjangkau }\end{array}$ \\
\hline & & \multirow[t]{3}{*}{ Perekonomian } & Pertokoan & $\begin{array}{l}\text { Luas jangkauan } \\
\text { berdasarkan } \\
\text { standart jarak } \\
\text { jangkauan } \\
\text { pelayanan }\end{array}$ & & $\begin{array}{c}\text { Seluruh } \\
\text { kawasan } \\
\text { terjangkau }\end{array}$ & $\begin{array}{c}\text { Terdapat } \\
\text { kawasan yang } \\
\text { tidak } \\
\text { terjangkau }\end{array}$ \\
\hline & & & $\begin{array}{c}\text { Pusat } \\
\text { perbelajaan }\end{array}$ & $\begin{array}{l}\text { Luas jangkauan } \\
\text { berdasarkan } \\
\text { standart jarak } \\
\text { jangkauan } \\
\text { pelayanan } \\
\end{array}$ & & $\begin{array}{c}\text { Seluruh } \\
\text { kawasan } \\
\text { terjangkau }\end{array}$ & $\begin{array}{c}\text { Terdapat } \\
\text { kawasan yang } \\
\text { tidak } \\
\text { terjangkau }\end{array}$ \\
\hline & & & pasar & $\begin{array}{l}\text { Luas jangkauan } \\
\text { berdasarkan } \\
\text { standart jarak } \\
\text { jangkauan } \\
\text { pelayanan }\end{array}$ & & $\begin{array}{c}\text { Seluruh } \\
\text { kawasan } \\
\text { terjangkau }\end{array}$ & $\begin{array}{c}\text { Terdapat } \\
\text { kawasan yang } \\
\text { tidak } \\
\text { terjangkau }\end{array}$ \\
\hline & & \multirow[t]{3}{*}{$\begin{array}{c}\text { Pelayanan } \\
\text { Pemerintahan }\end{array}$} & Kantor Pos & $\begin{array}{l}\text { Luas jangkauan } \\
\text { berdasarkan } \\
\text { standart jarak } \\
\text { jangkauan } \\
\text { pelayanan }\end{array}$ & & $\begin{array}{c}\text { Seluruh } \\
\text { kawasan } \\
\text { terjangkau }\end{array}$ & $\begin{array}{c}\text { Terdapat } \\
\text { kawasan yang } \\
\text { tidak } \\
\text { terjangkau }\end{array}$ \\
\hline & & & Kantor Polis & $\begin{array}{l}\text { Luas jangkauan } \\
\text { berdasarkan } \\
\text { standart jarak } \\
\text { jangkauan } \\
\text { pelayanan } \\
\end{array}$ & & $\begin{array}{c}\text { Seluruh } \\
\text { kawasan } \\
\text { terjangkau }\end{array}$ & $\begin{array}{c}\text { Terdapat } \\
\text { kawasan yang } \\
\text { tidak } \\
\text { terjangkau }\end{array}$ \\
\hline & & & $\begin{array}{c}\text { Kantor } \\
\text { Pemadam } \\
\text { Kebakaran }\end{array}$ & $\begin{array}{l}\text { Luas jangkauan } \\
\text { berdasarkan } \\
\text { standart jarak } \\
\text { jangkauan } \\
\text { pelayanan } \\
\end{array}$ & & $\begin{array}{c}\text { Seluruh } \\
\text { kawasan } \\
\text { terjangkau }\end{array}$ & $\begin{array}{c}\text { Terdapat } \\
\text { kawasan yang } \\
\text { tidak } \\
\text { terjangkau }\end{array}$ \\
\hline & & \multirow[t]{2}{*}{ Peribadatan } & Masjid & $\begin{array}{l}\text { Luas jangkauan } \\
\text { berdasarkan } \\
\text { standart jarak } \\
\text { jangkauan } \\
\text { pelayanan }\end{array}$ & & $\begin{array}{c}\text { Seluruh } \\
\text { kawasan } \\
\text { terjangkau }\end{array}$ & $\begin{array}{c}\text { Terdapat } \\
\text { kawasan yang } \\
\text { tidak } \\
\text { terjangkau }\end{array}$ \\
\hline & & & Gereja & $\begin{array}{l}\text { Luas jangkauan } \\
\text { berdasarkan } \\
\text { standart jarak } \\
\text { jangkauan } \\
\text { pelayanan }\end{array}$ & & $\begin{array}{l}\text { Seluruh } \\
\text { kawasan } \\
\text { terjangkau }\end{array}$ & $\begin{array}{c}\text { Terdapat } \\
\text { kawasan yang } \\
\text { tidak } \\
\text { terjangkau }\end{array}$ \\
\hline & & Rekreasi & Taman Kota & $\begin{array}{l}\text { Luas jangkauan } \\
\text { berdasarkan } \\
\text { standart jarak } \\
\text { jangkauan } \\
\text { pelayanan } \\
\end{array}$ & & $\begin{array}{c}\text { Seluruh } \\
\text { kawasan } \\
\text { terjangkau }\end{array}$ & $\begin{array}{c}\text { Terdapat } \\
\text { kawasan yang } \\
\text { tidak } \\
\text { terjangkau }\end{array}$ \\
\hline & & kebudayaan & theater & $\begin{array}{l}\text { Luas jangkauan } \\
\text { berdasarkan } \\
\text { standart jarak } \\
\text { jangkauan } \\
\text { pelayanan }\end{array}$ & & $\begin{array}{c}\text { Seluruh } \\
\text { kawasan } \\
\text { terjangkau }\end{array}$ & $\begin{array}{c}\text { Terdapat } \\
\text { kawasan yang } \\
\text { tidak } \\
\text { terjangkau }\end{array}$ \\
\hline & & \multirow[t]{2}{*}{ transpotrtasi } & Terminasl & $\begin{array}{l}\text { Luas jangkauan } \\
\text { berdasarkan } \\
\text { standart jarak } \\
\text { jangkauan } \\
\text { pelayanan }\end{array}$ & & $\begin{array}{l}\text { Seluruh } \\
\text { kawasan } \\
\text { terjangkau }\end{array}$ & $\begin{array}{c}\text { Terdapat } \\
\text { kawasan yang } \\
\text { tidak } \\
\text { terjangkau }\end{array}$ \\
\hline & & & $\begin{array}{c}\text { Stasiun kereta } \\
\text { api }\end{array}$ & $\begin{array}{l}\text { Luas jangkauan } \\
\text { berdasarkan } \\
\text { standart jarak }\end{array}$ & & $\begin{array}{c}\text { Seluruh } \\
\text { kawasan } \\
\text { terjangkau }\end{array}$ & $\begin{array}{c}\text { Terdapat } \\
\text { kawasan yang } \\
\text { tidak }\end{array}$ \\
\hline
\end{tabular}


Sri Murdiati Rin Permata Sari, Efektivitas Pusat Pelayanan...

\begin{tabular}{|c|c|c|c|c|c|c|c|}
\hline \multirow{2}{*}{ Variabel } & \multirow{2}{*}{$\begin{array}{c}\text { Definisi } \\
\text { Variabel }\end{array}$} & \multirow{2}{*}{ Sub-Variabel } & \multirow{2}{*}{ Jenis Sarana } & \multirow{2}{*}{ Parameter } & \multirow{2}{*}{ Sumber } & \multicolumn{2}{|c|}{ Indikator } \\
\cline { 6 - 7 } & & & & $\begin{array}{l}\text { jangkauan } \\
\text { pelayanan }\end{array}$ & & & $\begin{array}{c}\text { Tidak Sesuai } \\
\text { (1) }\end{array}$ \\
\cline { 6 - 8 } & & & & & & terjangkau \\
\hline
\end{tabular}

Sumber : Mirsa, 2012 ; Chiara, 1995; SNI 03-1733-2004 Tentang Tata Cara Perencanaan

Lingkungan Perumahan di Perkotaan

\subsection{Kerangka Rancangan Penelitian}

Kerangka rancangan penelitian merupakan gambaran mengenai proses/tahapan dalam melaksanakan penelitian yang terdiri dari tahapan persiapan dan tahap pelaksanaan.

\subsubsection{Tahap Persiapan}

Tahap persiapan merupakan tahapan sebelum dilaksanakannya penelitian. Tahap persiapan diawali dengan penentuan tema, topik, dan judul penelitian, yang kemudian dilakukan langkah lebih lanjut yaitu observasi awal mengenai gambaran umum wilayah penelitian serta melakukan studi dokumen penelitian dan jurnal yang terkait dengan penelitian yang akan dilakukan, untuk menyusun latar belakang penelitian, menentukan rumusan masalah, menentukan variabel penelitian, merumuskan metode penelitian, hingga menentukan sampel dari populasi yang akan diambil sebagai sumber informasi. Pada akhirnya semua hal tersebut disusun, distrukturkan, dan dituangkan ke dalam proposal penelitian.

\subsubsection{Tahap Pelaksanaan}

Tahap pelaksanaan penelitian terdiri dari tahap pengumpulan data, tahap analisis data, dan tahap penyusunan hasil penelitian.

Pengumpulan dan Kompilasi Data

Tahap pengumpulan data dilakukan untuk mengumpulkan data yang dibutuhkan, baik melalui survey data primer kepada masyarakat dan observasi lapangan maupun survey data sekunder kepada instansi pemerintah yang dianggap memiliki data yang dibutuhkan, dimana pada penelitian ini instansi yang dituju adalah Bappeda Kabupaten Sragen, Kantor Kecamatan Gemolong, Kantor Kecamatan Kawasan Hinterland Gemolong, dan Kantor
Kelurahan di Kecamatan Gemolong Serta instansi dinas terkait lainnya yang memiliki data yang dibutuhkan oleh peneliti. Kegiatan survey dilakukan dengan terlebih dahulu menyusun instrumen survey yang berupa ceklist data, kuesioner, dan borang peta. Kemudian dilakukan pengumpulan data dan melakukan kompilasi data (interpretasi data) yaitu menyusun datadata yang telah didapatkan agar lebih mudah dibaca dan dipahami.

Analisis Data

Tahap analisis data bertujuan untuk menghasilkan output yang dapat menjawab pertanyaan penelitian. Analisis dilakukan dengan teknik analisis skoring untuk mengetahui tingkat efektivitas kecamatan Gemolong sebagai wilayah pusat pelayanan di Kabupaten Sragen.

Penyusunan Hasil Penelitian

Setelah analisis dilakukan, maka tahapan selanjutnya adalah penyusunan laporan penelitian yang berisi keseluruhan hasil dari kegiatan pada tahapan persiapan penelitian hingga tahap pelaksanaan penelitian. Hasil dari kegiatan ditarik pada sebuah kesimpulan yang disertai rekomendasi untuk penelitian selanjutnya.

\subsection{Teknik Analisis Data}

Analisis untuk efektivitas perkotaan gemolong sebagai pusat pelayananpermukiman di Kabupaten sragen ini merupakan step setelah identifikasi terhadap kondisi , jangkauan pada masing-masing pelayanan. Analisis ini mengidentifikasi tingkat keefektifan dari gemolong sebagai pusat pelayanan yang pada akhirnya menetapkan tingkat efektifan pada ukuran mendekati efektif; mendekati efektif dan tidak efektif; mendekati tidak efektif. Analisis ini dilakukan dengan skoring bertingkat. Bermula dari skoring pada masing- 
masing sarana pelayanan pada jenis pelayanan yang menggunakan analisis kesesuaian sehingga terdapat dua indikator yaitu sesuai dan tidak sesuai, kemudian dirumuskan untuk kesesuaian masing-masing jenis pelayanan berdasarkan hasil skoring dari masingmasing sarana, kemudian dilakukan perumusan kesesuaian kembali pada variabel tujuan pelayanan permukiman, efisiensi pelayanan permukiman dan keterjangkauan pelayanan permukiman. Setelah didapatkan nilai kesesuaian pada tiap variabel (tujuan, efisiensi dan keterjangkauan), maka dapat dihitung nilai efektivitasnya dengan klasifikasi efektivitas adalah mendekati efektif; mendekati efektiv dan tidak efektiv; mendekati tidak efektif.

\subsubsection{Penilaian Kesesuaian Pada Masing-Masing Jenis Pelayanan Pada Masing-Masing Variabel}

Penilaian kesesuaian pada masingmasing variabel didasari oleh nilai kesesuaian dari masing-masing sarana pelayanan yang bernilai 1 (tidak sesuai) atau 2 (sesuai). Kemudian dari nilai kesesuaian dapat dianalisis nilai kesesuaian dari tujuan, efisiensi ataupun keterjangkauan dari masing-masing jenis pelayanan dengan perumusan sebagai berikut :

interval $=\frac{(\text { totalskortertinggi })-(\text { totalskorterendah })}{\text { jumlahkelas }}$

Interval :x

Tabel 4. Nilai Kesesuaian Pelayanan

\begin{tabular}{|l|c|c|}
\hline \multicolumn{1}{|c|}{ Nilai Kesesuaian Tujuan } & Nilai & Keterangan \\
\hline $\begin{array}{l}\text { Total skor (total terendah }+\mathrm{x} \\
+0,1)-(\text { total tertinggi) }\end{array}$ & 2 & Sesuai \\
\hline $\begin{array}{l}\text { Total skor (total terendah) }- \\
\text { (total terendah }+\mathrm{x})\end{array}$ & 1 & Tidak Sesuai \\
\hline
\end{tabular}

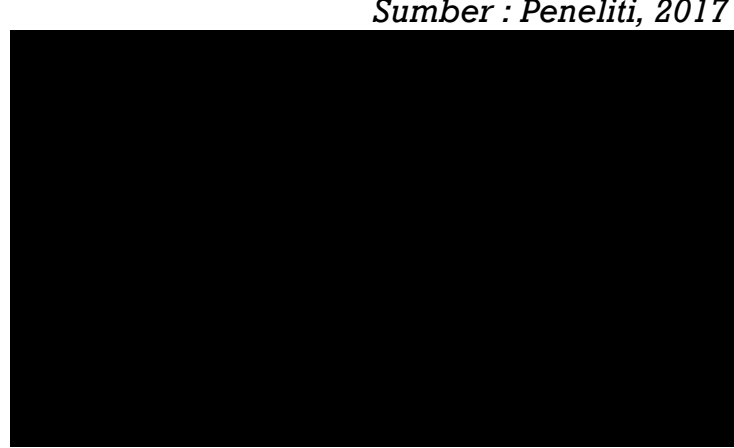

Gambar 2. Bagan Tahapan Analisis Tujuan
(Analisis Peneliti, 2017)

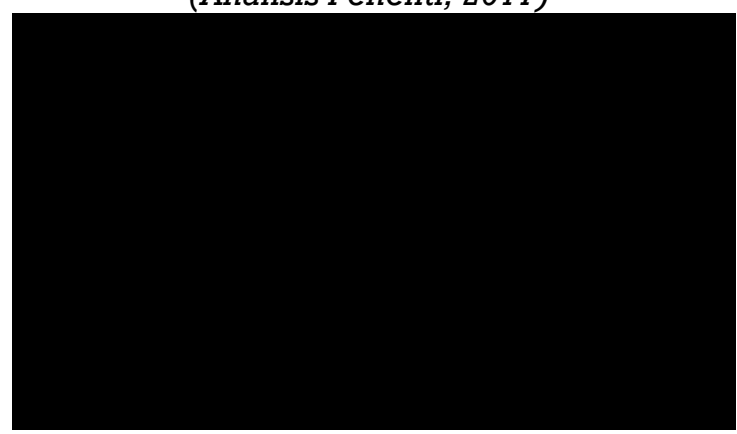

Gambar 3. Bagan Tahapan Analisis Efisiensi (Analisis Peneliti, 2017)

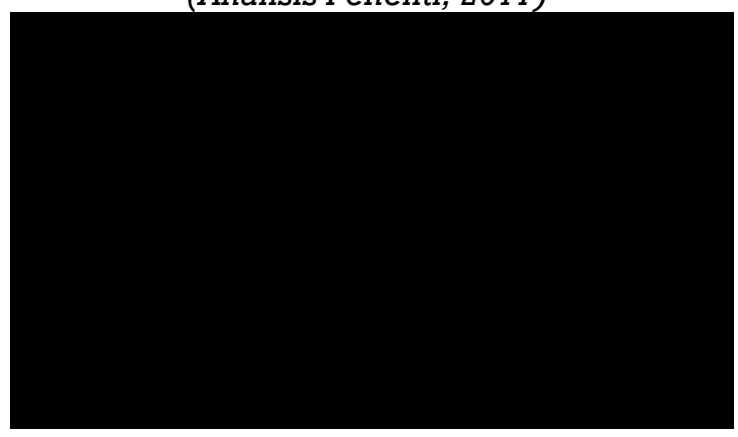

Gambar 4. Bagan Tahapan Analisis Keterjangkauan

(Analisis Peneliti, 2017)

\subsubsection{Tingkat Efelktivitas Perkotaan Gemolong sebagai Pusat Pelayanan Permukiman di Kabupaten Sragen}

Untuk menghitung nilai efektivitas dari perkotaan gemolong sebagai pusat pelayanan permukiman di Kabupaten Sragen adalah berdasarkan nilai hasil kesesuaian dari ke tiga variabel, yaitu tujuan, efisiensi dan keterjangkauan pelayanan dengan perhitungan berdasarkan pendekatan kuantitatif dengan cara presentase. Cara presentase ini digunakan untuk mempermudah dalam hal intrepetasi hasil analisis keseuaian pada tiap variabel efektivitas dalam menilai efektivitas pusat pelayanan permukiman [Sugiono, 1999]. Dengan perhitungan sebagai berikut :

Presentasenilai $=\frac{\text { jumlah total nilai }}{\text { (jumlahtotalnilaitertinggi) }} \times 100 \%$

Jumlah total nilai tertinggi yang dimungkinkan untuk nilai total efektivitas pusat pelayanan permukiman 6 , berdasarkan terdapat tiga variabel dengan kemungkinan nilai tertinggi adalah dua. Interpretasi terhadap nilai 
efektivitas pusat pelayanan permukiman dengan menggunakan pengklasifikasian pendekatan kuantitatif, yaitu dengan tiga rentang presentase, mendekati sesuai; mendekati sesuai dan tidak sesuai; dan mendekati tidak sesuai. Digunakan rentang presentase agar jika presentase nilai dari efektivitas pusat pelayanan adalah misal 25\%, hal tersebut tidak kemudian dinilai tidak sesuai atau bernilai $0 \%$ tetapi digunakan rentang presentase yaitu mendekati tidak sesuai (meminimalisir penghilangan nilai). Berikut adalah rentang presentase skala guttman yang digunakan untuk presentase nilai efektivitas pusat pelayanan permukiman [Sugiyono, 1999]:

a. Apabila presentase nilai efektivitas pusat pelayanan permukiman berada dalam rentang skala 0-49\%, maka efektivitas pusat pelayanan permukiman tersebut dinyatakan dengan "mendekati tidak efektif" berdasarkan variabel efektivitas,

b. Apabila presentase nilai efektivitas pusat pelayanan permukiman bernilai $50 \%$ maka efektivitas pusat pelayanan permukiman tersebut dinyatakan "mendekati tidak efektif dan efektif" berdasarkan variabel efektivitas,

c. Apabila presentase nilai efektivitas pusat pelayanan permukiman berada dalam rentang skor 51-100\%, maka efektivitas pusat pelayanan permukiman tersebut dinyatakan "mendekati efektif" berdasarkan variabel efektivitas.

\section{HASIL DAN PEMBAHASAN}

\subsection{Kesesuaian Permukiman}

Berdasarkan analisis yang telah dilakukan, didapatkan nilai untuk masing-masing kesesuaian pada masing-masing variabel adalah sebagai berikut :

Tabel 5. Nilai Kesesuaian Tujuan Pelayanan

\begin{tabular}{|l|l|c|c|}
\hline No & Jenis Pelayanan & Nilai & Kesesuaian \\
\hline 1 & Pendidikan & 1 & Tidak Sesuai \\
\hline 2 & Kesehatan & 2 & Sesuai \\
\hline 3 & Perekonomian & 1 & Tidak Sesuai \\
\hline 4 & Pemerintahan & 2 & Sesuai \\
\hline
\end{tabular}

\begin{tabular}{|c|c|c|c|}
\hline No & Jenis Pelayanan & Nilai & Kesesuaian \\
\hline 5 & Peribadatan & 2 & Sesuai \\
\hline 6 & Rekreasi & 2 & Sesuai \\
\hline 7 & Kebudayaan & 1 & Tidak Sesuai \\
\hline 8 & Transportasi & 2 & Sesuai \\
\hline \multirow{2}{*}{\multicolumn{2}{|c|}{$\begin{array}{l}\text { Total } \\
\text { Nilai Kesesuaian Tujuan } \\
\text { Pelayanan Permukiman }\end{array}$}} & 13 & \\
\hline & & 2 & Tidak Sesuai \\
\hline
\end{tabular}

Sumber : Analisis Peneliti, 2017

Tabel 6. Nilai Kesesuaian Efisiensi Pelayanan

\begin{tabular}{|l|l|c|c|}
\hline No & Jenis Pelayanan & Nilai & Keterangan \\
\hline 1 & Pendidikan & 1 & Tidak Sesuai \\
\hline 2 & Kesehatan & 1 & Tidak Sesuai \\
\hline 3 & Perekonomian & 2 & Sesuai \\
\hline 4 & Pemerintahan & 1 & Tidak Sesuai \\
\hline 5 & Peribadatan & 1 & Tidak Sesuai \\
\hline 6 & Rekreasi & 1 & Tidak Sesuai \\
\hline 7 & Kebudayaan & 1 & Tidak Sesuai \\
\hline 8 & Transportasi & 2 & Sesuai \\
\hline Total & 10 & \\
\hline $\begin{array}{l}\text { Nilai Kesesuaian Efisiensi } \\
\text { Pelayanan Permukiman }\end{array}$ & 1 & Tidak Sesuai \\
\hline
\end{tabular}

Sumber : Analisis Peneliti, 2017

Tabel 7. Nilai Kesesuaian Keterjangkauan Pelayanan

\begin{tabular}{|c|c|c|c|}
\hline No & Jenis Pelayanan & Nilai & Keterangan \\
\hline 1 & Pendidikan & 1 & Tidak Sesuai \\
\hline 2 & Kesehatan & 1 & Tidak Sesuai \\
\hline 3 & Perekonomian & 2 & Sesuai \\
\hline 4 & Pemerintahan & 2 & Sesuai \\
\hline 5 & Peribadatan & 1 & Tidak Sesuai \\
\hline 6 & Rekreasi & 2 & Sesuai \\
\hline 7 & Kebudayaan & 1 & Tidak Sesuai \\
\hline 8 & Transportasi & 1 & Tidak Sesuai \\
\hline \multicolumn{2}{|r|}{ Total } & 11 & \\
\hline \multicolumn{2}{|c|}{$\begin{array}{c}\text { Nilai Kesesuaian } \\
\text { Keterjangkauan } \\
\text { Pelayanan Permukiman }\end{array}$} & 1 & Tidak Sesuai \\
\hline
\end{tabular}

Sumber : Analisis Peneliti, 2017

\subsection{Tinglkat Efektivitas Pelayanan Permukiman}

Untuk kesesuaian tujuan pelayanan permukiman adalah sesuai (2), kesesuaian efisiensi pelayanan permukiman adalah tidak sesuai (1), dan kesesuaian keterjangkauan pelayanan permukiman adalah tidak sesuai (1). Sehingga untuk mengetahui nilai efektivitas pelayanan permukiman ini berdasarkan pada tiga variabel awal yaitu tujuan, efisiensi dan keterjangkauan dengan nilai masingmasing variabel tersebut setelah dilakukan analisis adalah sebagai berikut :

$$
\begin{gathered}
\text { Presentasenilai }=\frac{\text { jumlah total nilai }}{\text { (jumlahtotalnilaitertinggi) }} \times 100 \% \\
\text { Presentasenilai }=\frac{4}{(6)} \times 100 \%
\end{gathered}
$$


Presentasenilai 66,7 \%

Dari hasil perhitungan diatas maka dapat diketahui bahwa untuk nilai efektivitas perkotaan gemolong sebagai pusat pelayanan permukiman dengan presentase sebesar $66,7 \%$ yang berarti adalah "mendekati efektif".

\subsection{Efektivitas Perkotaan Gemolong Sebagai Pusat Pelayanan Permukiman}

Efektivitas perkotaan Gemolong sebagai pusat pelayanan permukiman merupakan pengukuran dalam tercapainya keberhasilan perkotaan Gemolong yang berperan sebagai pusat pelayanan permukiman di Kabupaten Sragen khususnya terhadap kawasan pelayanan yang dilayani yang dilihat dari sisi tujuan, efisiensi dan keterjangkauan. Berdasarkan analisis yang dilakukan, efektivitas perkotaan Gemolong sebagai pusat pelayanan permukiman di dapatkan dengan pendekatan presentase nilai kesesuaian dari tiga variabel tujuan, efisiensi dan keterjangkauan.

Tujuan pelayanan permukiman yang ada telah sesuai dengan indikator kesesuaian yang dirumuskan, hal ini berarti pelayanan permukiman di perkotaan Gemolong telah dapat melayani dengan baik sesuai dengan masing-masing fungsi utama pelayanan. Secara garis besar bahwa fungsi pelayanan permukiman telah terpenuhi dengan baik oleh perkotaan Gemolong. Efisiensi pelayanan permukiman yang ada belum sesuai dengan indikator kesesuaian yang dirumuskan, hal ini berarti walaupun ada beberapa pelayanan yang efisiensi pelayanannya sesuai namun hal itu tidak memberikan efek besar karena sebagian besar pelayanan yang ada tidak sesuai untuk efisiensi pelayanannya. Dari sini dapat diketahui bahwa untuk ketersediaan sarana pelayanan permukiman di perkotaan Gemolong masih belum sesuai dengan kebutuhan sarana pelayanan penduduk dan tidak seimbang dengan jumlah penduduk yang ada di kawasan pelayanan dan kawasan perkotaan. Adanya kekurangan ketersediaan sarana pelayanan ini mengakibatkan adanya overload pelayanan pada sarana yang telah ada, sarana yang telah ada kemudian harus melayani jumlah yang lebih besar dari seharusnya dan menjadikan kinerja pelayanan tidak optimal. Dampak kedepannya masyarakat tidak nyaman karena berebut, atau mengantri terlalu panjang untuk mendapatkan pelayanan yang dibutuhkan dan kemudian menuju ke pelayanan di kota lain yang memiliki ketersediaan sarana yang lebih baik.

Keterjangkauan pelayanan permukiman yang ada belum sesuai dengan indikator kesesuaian yang dirumuskan, hal ini berarti walaupun ada beberapa pelayanan yang dapat menjangkau seluruh kawasan namun sebagian besar pelayanan tidak dapat menjangkau seluruh kawasan. Kawasan yang tidak terjangkau oleh pelayanan tersebut kemudian akan cenderung memenuhi kebutuhan dalam permukimannya ke kota lain yang memiliki jarak lebih dekat dan lebih terjangkau dari sisi jaraknya. Keterjangkauan pelayanan permukiman ini dapat menjangkau seluruh kawasan jika sarana pelayanan sejenis yang ada di perkotaan Gemolong tidak terpusat pada satu bagian kawasan (jangan terlalu berdekatan, jangan berada pada satu ruas jalan yang sama), sehingga daya jangkau nya akan lebih luas serta perlu adanya penambahan sarana pelayanan untuk pelayanan yang belum ada serta penggeseran sarana agar berada di tengah kawasan sehingga menjangkau seluruh kawasan pelayanan dan perkotaan.

Tujuan pelayanan, efisiensi pelayanan dan keterjangkauan pelayanan merupakan variabel untuk menilai efektivitas perkotaan Gemolong sebagai pusat pelayanan permukiman di Kabupaten Sragen, sehingga masingmasing variabel memiliki andil dalam menentukan nilai efektivitasnya. Berdasarkan analisis, yang sesuai dengan nilai kesesuaian hanyalah variabel tujuan pelayanan sedangkan 
untuk variabel efisiensi dan keterjangkauan tidak sesuai.

Dengan pendekatan presentase diketahui bahwa presentase efektivitas perkotaan Gemolong sebagai pusat pelayanan permukiman adalah 66,7\% yang berarti bahwa "mendekati efektif". Mendekati efektif disini diartikan bahwa perkotaan Gemolong sebagai pusat pelayanan permukiman berada pada posisi mendekati berhasil (mendekati efektif) dalam memenuhi perannya sebagai pusat pelayanan permukiman baik dari sisi tujuan, efisiensi ataupun keterjangkauan. Disebut mendekati berhasil karena dari tiga vaiabel pendekatan, terdapat pendekatan yang menyatakan bahwa dilihat dari sisi tujuan, perkotaan Gemolong telah sesuai (efektif dari sisi tujuan). Dari pendekatan keterjangkauan dan efisiensi yang merupakan bagaimana masyarakat untuk dapat menjangkau pelayanan serta bagaimana ketersediaan jumlah sarana jika dibandingkan dengan jumlah penduduk masih belum sesuai (belum efektif). Perkotaan Gemolong perlu meningkatkan lagi pelayanan permukiman yang ada khususnya dari pendekatan efisiensi dan keterjangkauan agar dapat memenuhi fungsi dan perannya sebagai pusat pelayanan permukiman, dengan beberapa cara yaitu penambahan jumlah sarana pelayanan permukiman, pergeseran dan pengaturan tata letak sarana agar kebutuhan ketersediaan sarana dan keterjangkauan sarana terpenuhi.

\section{KESIMPULAN}

Kesimpulan yang didapatkan baik selama penelitian berlangsung ataupun hasil dari penelitian, serta saran baik untuk hasil penelitian serta penelitian selanjutnya adalah sebagai berikut.

\subsection{Kesimpulan}

Penelitian efektivitas perkotaan Gemolong sebagai pusat pelayanan permukiman di Kabupaten Sragen ini selama proses penelitian dan berdasarkan analisis menemukan banyak hal dan dapat ditarik beberapa kesimpulan sebagai berikut :

a. Efektivitas perkotaan Gemolong sebagai pusat pelayanan permukiman dengan pendekatan tujuan adalah satu-satunya variabel yang telah memenuhi indikator dan kesesuaian, yang artinya bahwa Perkotaan Gemolong telah efektif dan berhasil menjadi pusat pelayanan permukiman jika dilihat dari sisi ketercapaian fungsi pelayanan

b. Pemenuhan kebutuhan pelayanan dan keterjangkauan pelayanan belum sesuai atau belum terpenuhi oleh perkotaan Gemolong sebagai perannya sebgai pusat pelayanan permukiman bagi kawasan pelayanan. Masih ada pelayanan yang belum cukup (jumlahnya) dan masih ada kawasan pelayanan yang belum terjangkau oleh pelayanan permukiman.

c. Tingkat efektivitas perkotaan Gemolong sebagai pusat pelayanan permukiman di Kabupaten Sragen adalah mendekati efektif ini berarti peran Perkotaan Gemolong sudah cukup baik namun belum optimal sehingga harus terus ditingkatkan

d. Kekurangan ketersediaan sarana pelayanan, berimplementasi kepada masyarakat untuk memenuhi kebutuhan pelayanannya di kota sekitar (Solo, Porwodadi, Boyolali) yang memeiliki ketersediaan yang lebih lengkap.

e. Kawasan yang tidak terjangkau oleh pelayanan permukiman cenderung akan memenuhi pelayanannya di kota kota sekitar (Solo, Porwodadi, Boyolali) yang memiliki jarak lebih dekat dan lebih terjangkau (dari sisi jarak) daripada perkotaan Gemolong.

f. Agar efektivitas perkotaan Gemolong sebagai pusat pelayanan permukiman di Kabupaten Sragen efektif, maka diperlukan adanya penambahan jumlah ketersediaan sarana pelayanan agar sesuai dengan kebutuhan dan seimbang dengan 
jumlah penduduk, serta adanya pengaturan tata letak sarana pelayanan permukiman agar dapat menjangkau seluruh kawasan baik kawasan pelayanan ataupun kawasan perkotaan.

\subsection{Saran}

Saran yang dapat peneliti sampaiakan setalah melakukan proses penelitian ini antara lain sebagai berikut :

a. Perlunya penambahan jumlah pelayanan permukiman (khususnya yang masing kurang) di perkotaan Gemolong guna memenuhi kebutuhan pelayanan masyarakat terhadap pelayanan permukiman

b. Pembangunan sarana pelayanan permukiman yang lebih menyebar, serta adanya pengaturan tata letak sehingga tidak tersentral dalam satu blok serta dapat memperluas daya jangkau (khususnya pada kawasan yang belum terjangkau).

c. Untuk penelitian selanjutnya dapat meneliti bagaimana kecenderungan masyarakat pada kawasan pelayanan dalam memenuhi kebutuhannya, karena letak geografis kawasan pelayanan yang strategis dekat dengan orde lain yang lebih tinggi sehingga menimbulkan magenet baru untuk masyarakat untuk lebih cenderung memenuhi kebutuhannya di kota sekitar daripada di perkotaan Gemolong.

\section{DAFTAR PUSTAKA}

Chiara, Joseph De. 1995. Time Saver Standards For Housing and Residential Development. USA : McGraw-Hill, Inc

Daljoeni, N. 1992. Geografi Kota dan Desa. Bandung : Penerbit Alumni

Elisa. 2015. Model Pembangunan Wilayah. Yogyakarta : Universitas Gadjah Mada

Gallion, Arthur B and Simon Eisner. 1975. The Urban Pattern, City Planning and Design. London : Litton Educational Publishing, inc.
Handayaningrat, Soewarno. 1994. Pengantar Studi Ilmu Administrasi dan Manajemen. Jakarta : CV Haji Masagung.

Mirsa, Rinaldi. 2012. Elemen Tata Ruang Kota. Yogyakarta : Graha Ilmu,

Muta'ali, Lutfi. 2014. Perencanaan Pengembangan Wilayah, Berbasis Pengurangan Risiko Bencana. Yogyakarta : Universitas Gadjah Mada.

Peraturan Menkes no.134/Menkes/sk/IV/1978

Permen PU No. 05/PRT/M/2008

Pontoh, Nia K dan Iwan Kustiwan. 2009. Pengantar Perencanaan Perkotaan. Bandung : Institut Teknoogi Bandung

PP RI No.37 Tahun 1985 tentang Penyelenggaraan Pos

Putri, Duta Hestuadi. 2007. Peran Dan Fungsi Ibu Kota Kecamatan Lasem Sebagai Pusat Pertumbuhan Di Kabupaten Rembang. Semarang : Universitas Diponegoro

Rencana Tata Ruang Wilayah Kabupaten Sragen Tahun 2009-2029

Rustiadi, Ernan. 2011. Perencanaan dan Pengembangan Wilayah. Jakarta : Yayasan Pustaka Obor Indonesia

SNI 03-3647-1994 tentang Tata Cara Perencanaan Teknik Bangunan Gedung Olahraga

SNI 03-1733-2004 tentang Perencanaan Permukiman Perkotaan

Silalahi, Ulber. 2010. Metode Penelitian Sosial. Bandung : Refika Aditama

Sugiyono. 2011. Metode Penelitian Kuantitatif, Kualitatif dan $R \& D$. Bandung : Alfabeta

Sugiyono. 2015. Metode Penelitian dan Pengembangan. Bandung : Alfabeta

Sujarto, Djoko. 2012. Perencanaan Kota Baru. Bandung : Institut Teknoogi Bandung

Tamin, Ofyar Z. 2000. Perencanaan dan Pemodelan Transportasi. Bandung : ITB

Yunus, Hadi Sabari. 2005. Klasifikasi Kota. Yogyakarta : Pustaka Pelajar. 